\title{
Cannabidiol as a Promising Strategy to Treat and Prevent Movement Disorders?
}

\author{
Fernanda F. Peres ${ }^{1,2 * t}$, Alvaro C. Lima ${ }^{1 \dagger}$, Jaime E. C. Hallak ${ }^{2,3}$, José A. Crippa ${ }^{2,3}$, \\ Regina H. Silva ${ }^{1}$ and Vanessa C. Abilio ${ }^{1,2}$
}

1 Laboratory of Behavioral Neurosciences, Department of Pharmacology, Federal University of São Paulo, São Paulo, Brazil, ${ }^{2}$ National Institute for Translational Medicine (INCT-TM, CNPq, FAPESP, CAPES), Ribeirão Preto, Brazil, ${ }^{3}$ Department of Neuroscience and Behavior, University of São Paulo, Ribeirão Preto, Brazil

\section{OPEN ACCESS}

Edited by:

Fabricio A. Pamplona, Entourage Phytolab, Brazil

Reviewed by:

Rui Daniel Prediger, Universidade Federal de Santa

Catarina, Brazl

Giuseppe Di Giovanni, University of Malta, Malta

${ }^{*}$ Correspondence: Fernanda F. Peres fernandafperes@hotmail.com

tThese authors have contributed equally to this work.

Specialty section:

This article was submitted to

Neuropharmacology,

a section of the journal

Frontiers in Pharmacology

Received: 23 December 2017 Accepted: 24 April 2018 Published: 11 May 2018

Citation:

Peres FF, Lima AC, Hallak JEC, Crippa JA, Silva RH and Abílio VC (2018) Cannabidiol as a Promising

Strategy to Treat and Prevent Movement Disorders?

Front. Pharmacol. 9:482.

doi: 10.3389/fphar.2018.00482
Movement disorders such as Parkinson's disease and dyskinesia are highly debilitating conditions linked to oxidative stress and neurodegeneration. When available, the pharmacological therapies for these disorders are still mainly symptomatic, do not benefit all patients and induce severe side effects. Cannabidiol is a non-psychotomimetic compound from Cannabis sativa that presents antipsychotic, anxiolytic, anti-inflammatory, and neuroprotective effects. Although the studies that investigate the effects of this compound on movement disorders are surprisingly few, cannabidiol emerges as a promising compound to treat and/or prevent them. Here, we review these clinical and pre-clinical studies and draw attention to the potential of cannabidiol in this field.

Keywords: cannabidiol, movement disorders, Parkinson's disease, Huntington's disease, dystonic disorders, cannabinoids

\section{CANNABIDIOL (CBD)}

Cannabidiol (CBD) is one of the over 100 phytocannabinoids identified in Cannabis sativa (ElSohly and Gul, 2014), and constitutes up to $40 \%$ of the plant's extract, being the second most abundant component (Grlic, 1976). CBD was first isolated from marijuana in 1940 by Adams et al. (1940) and its structure was elucidated in 1963 by Mechoulam and Shvo (1963). Ten years later, PerezReyes et al. (1973) reported that, unlike the main constituent of cannabis $\Delta^{9}$-tetrahydrocannabinol $\left(\Delta^{9}\right.$-THC), CBD does not induce psychological effects, leading to the suggestion that CBD was an inactive drug. Nonetheless, subsequent studies demonstrated that CBD modulates the effects of $\Delta^{9}$ THC and displays multiple actions in the central nervous system, including antiepileptic, anxiolytic and antipsychotic effects (Zuardi, 2008).

Interestingly, $\mathrm{CBD}$ does not induce the cannabinoid tetrad, namely hypomotility, catalepsy, hypothermia, and antinociception. In fact, CBD mitigates the cataleptic effect of $\Delta^{9}$-THC (El-Alfy et al., 2010). Clinical and pre-clinical studies have pointed to beneficial effects of CBD on the treatment of movement disorders. The first studies investigated CBD's actions on dystonia, with encouraging results. More recently, the studies have been focusing on Parkinson's (PD) and Huntington's (HD) diseases. The mechanisms whereby CBD exerts its effects are still not completely understood, mainly because several targets have been identified. Of note, CBD displays anti-inflammatory and antioxidant actions (Campos et al., 2016), and both inflammation and oxidative stress are linked to the pathogenesis of various movement disorders, such as PD (Farooqui and Farooqui, 2011; Niranjan, 2014), HD (Sánchez-López et al., 2012), and tardive dyskinesia (Zhang et al., 2007). 
It is noteworthy that, when available, the pharmacological treatments for these movement disorders are mainly symptomatic and induce significant side effects (Connolly and Lang, 2014; Lerner et al., 2015; Dickey and La Spada, 2017). Nonetheless, despite its great clinical relevance, the studies evaluating CBD's role on the pharmacotherapy of movement disorders are surprisingly few. Here, we will review the clinical and pre-clinical evidence and draw attention to the potential of CBD in this field.

\section{CBD'S MECHANISMS OF ACTION}

CBD has several molecular targets, and new ones are currently being uncovered. $\mathrm{CBD}$ antagonizes the action of $\mathrm{CB}_{1}$ and $\mathrm{CB}_{2}$ receptors agonists, and is suggested to act as an inverse agonist of these receptors (Pertwee, 2008). Moreover, recent evidence point to $\mathrm{CBD}$ as a non-competitive negative allosteric modulator of $\mathrm{CB}_{1}$ and $\mathrm{CB}_{2}$ (Laprairie et al., 2015; MartínezPinilla et al., 2017). CBD is also an agonist of the vanilloid receptor TRPV1 (Bisogno et al., 2001), and the previous administration of a TRPV1 antagonist blocks some of CBD effects (Long et al., 2006; Hassan et al., 2014). In parallel, CBD inhibits the enzymatic hydrolysis and the uptake of the main endocannabinoid anandamide (Bisogno et al., 2001), an agonist of $\mathrm{CB}_{1}, \mathrm{CB}_{2}$ and TRPV1 receptors (Pertwee and Ross, 2002; Ross, 2003). The increase in anandamide levels induced by CBD seems to mediate some of its effects (Leweke et al., 2012). Moreover, in some behavioral paradigms the administration of an inhibitor of anandamide metabolism promotes effects similar to CBD (Pedrazzi et al., 2015; Stern et al., 2017).

CBD has also been shown to facilitate the neurotransmission mediated by the serotonin receptor $5-\mathrm{HT}_{1 \mathrm{~A}}$. It was initially suggested that CBD would act as an agonist of $5-\mathrm{HT}_{1 \mathrm{~A}}$ (Russo et al., 2005), but the latest reports propose that this interaction might be allosteric or through an indirect mechanism (Rock et al., 2012). Although this interaction is not fully elucidated, multiple CBD's effects were reported to depend on $5-\mathrm{HT}_{1 \mathrm{~A}}$ activation (Espejo-Porras et al., 2013; Gomes et al., 2013; Pazos et al., 2013; Hind et al., 2016; Sartim et al., 2016; Lee et al., 2017).

The peroxisome proliferator-activated receptor $\gamma(\operatorname{PPAR} \gamma)$ is a nuclear receptor involved in glucose metabolism and lipid storage, and PPAR $\gamma$ ligands have been reported to display anti-inflammatory actions (O'Sullivan et al., 2009). Data show that CBD can activate this receptor (O'Sullivan et al., 2009), and some of CBD effects are blocked by PPAR $\gamma$ antagonists (Esposito et al., 2011; Dos-Santos-Pereira et al., 2016; Hind et al., 2016). CBD also up-regulates PPAR $\gamma$ in a mice model of multiple sclerosis, an effect suggested to mediate the CBD's anti-inflammatory actions (Giacoppo et al., 2017b). In a rat model of Alzheimer's disease, CBD, through interaction with $\operatorname{PPAR} \gamma$, stimulates hippocampal neurogenesis, inhibits reactive gliosis, induces a decline in pro-inflammatory molecules, and consequently inhibits neurodegeneration (Esposito et al., 2011). Moreover, in an in vitro model of the blood-brain barrier,
$\mathrm{CBD}$ reduces the ischemia-induced increased permeability and VCAM-1 levels-both effects are attenuated by PPAR $\gamma$ antagonism (Hind et al., 2016).

CBD also antagonizes the G-protein-coupled receptor GPR55 (Ryberg et al., 2007). GPR55 has been suggested as a novel cannabinoid receptor (Ryberg et al., 2007), but this classification is controversial (Ross, 2009). Currently, the phospholipid lysophosphatidylinositol (LPI) is considered the GPR55 endogenous ligand (Morales and Reggio, 2017). Although only few studies link the CBD effect to its action on GPR55 (Kaplan et al., 2017), it is noteworthy that GPR55 has been associated with PD in an animal model (Celorrio et al., 2017) and with axon growth in vitro (Cherif et al., 2015).

More recently, $\mathrm{CBD}$ was reported to act as inverse agonist of the G-protein-coupled orphan receptors GPR3, GPR6, and GPR12 (Brown et al., 2017; Laun and Song, 2017). GPR6 has been implicated in both HD and PD. Concerning animal models of PD, GPR6 deficiency was related to both diminished dyskinesia after 6-OHDA lesion (Oeckl et al., 2014), and increased sensitivity to MPTP neurotoxicity (Oeckl and Ferger, 2016). Moreover, Hodges et al. (2006) described decreased expression of GPR6 in brain of HD patients, compared to control. GPR3 is suggested as a biomarker for the prognosis of multiple sclerosis (Hecker et al., 2011). In addition, GPR3, GPR6, and GPR12 have been implicated in cell survival and neurite outgrow (Morales et al., 2018).

CBD has also been reported to act on mitochondria. Chronic and acute CBD administration increases the activity of mitochondrial complexes (I, II, II-III, and IV), and of creatine kinase in the brain of rats (Valvassori et al., 2013). In a rodent model of iron overload-that induces pathological changes that resemble neurodegenerative disorders-CBD reverses the ironinduced epigenetic modification of mitochondrial DNA and the reduction of succinate dehydrogenase's activity (da Silva et al., 2018). Of note, multiple studies associate mitochondrial dysfunctions with the pathophysiology of PD (Ammal Kaidery and Thomas, 2018).

In parallel, several studies show anti-inflammatory and antioxidant actions of CBD (Campos et al., 2016). CBD treatment decreases the levels of the pro-inflammatory cytokines IL-1 $\beta$, TNF- $\alpha$, IFN- $\beta$, IFN- $\gamma$, IL-17, and IL-6 (Watzl et al., 1991; Weiss et al., 2006; Esposito et al., 2007, 2011; Kozela et al., 2010; Chen et al., 2016; Rajan et al., 2016; Giacoppo et al., 2017b), and increases the levels of the anti-inflammatory cytokines IL-4 and IL-10 (Weiss et al., 2006; Rajan et al., 2016). In addition, it inhibits the expression of iNOS (Esposito et al., 2007; Pan et al., 2009; Chen et al., 2016; Rajan et al., 2016) and COX-2 (Chen et al., 2016) induced by distinct mechanisms. CBD also displays antioxidant properties, being able to donate electrons under a variable voltage potential and to prevent the hydroperoxideinduced oxidative damage (Hampson et al., 1998). In rodent models of $\mathrm{PD}$ and $\mathrm{HD}, \mathrm{CBD}$ up-regulates the mRNA levels of the antioxidant enzyme superoxide dismutase (GarciaArencibia et al., 2007; Sagredo et al., 2007). In accordance, CBD decreases oxidative parameters in in vitro models of neurotoxicity (Hampson et al., 1998; Iuvone et al., 2004; Mecha et al., 2012). Of note, the anti-inflammatory and antioxidant effects of 
$\mathrm{CBD}$ on lipopolysaccharide-stimulated murine macrophages are suppressed by a TRPV1 antagonist (Rajan et al., 2016). It has also been shown that CBD can affect the expression of several genes involved in zinc homeostasis, which is suggested to be linked to its anti-inflammatory and antioxidant actions (Juknat et al., 2012).

CBD's mechanisms of action are summarized in Figure $\mathbf{1 .}$

\section{PARKINSON'S DISEASE (PD)}

PD is among the most common neurodegenerative disorders, with a prevalence that increases with age, affecting $1 \%$ of the population over 60 years old (Tysnes and Storstein, 2017). The disease is characterized by motor impairment (hypokinesia, tremors, muscle rigidity) and non-motor symptoms (e.g., sleep disturbances, cognitive deficits, anxiety, depression, psychotic symptoms) (Klockgether, 2004).

The pathophysiology of PD is mainly associated with the loss of midbrain dopaminergic neurons in the substantia nigra pars compacta (SNpc), with consequent reduced levels of dopamine in the striatum (Dauer and Przedborski, 2003). When the motor symptoms appear, about $60 \%$ of dopaminergic neurons is already lost (Dauer and Przedborski, 2003), hindering a possible early diagnosis. The most effective and used treatment for PD is L-DOPA, a precursor of dopamine that promotes an increase in the level of dopamine in the striatum, improving the motor symptoms (Connolly and Lang, 2014). However, after a long-term treatment the effect of L-DOPA can be unstable, presenting fluctuations in symptoms improvement (on / off effect) (Jankovic, 2005; Connolly and Lang, 2014). In addition, involuntary movements (namely L-DOPA-induced dyskinesia) appear in approximately $50 \%$ of the patients (Jankovic, 2005).

The first study with CBD on PD patients aimed to verify CBD's effects on the psychotic symptoms. Treatment with CBD for 4 weeks decreased the psychotic symptoms, evaluated by the Brief Psychiatric Rating Scale and the Parkinson Psychosis Questionnaire, without worsening the motor function or inducing adverse effects (Zuardi et al., 2009). Later, in a case series with four PD patients, it was verified that CBD is able to reduce the frequency of the events related to REM sleep behavior disorder (Chagas et al., 2014a). In addition, although not ameliorating PD patients' motor function or their general symptoms score, treatment with CBD for 6 weeks improves PD's patients quality of life (Chagas et al., 2014b). The authors suggest that this effect might be related to CBD's anxiolytic, antidepressant and antipsychotic properties (Chagas et al., 2014b).

Although the studies with patients with PD report beneficial effects of $\mathrm{CBD}$ only on the non-motor symptoms, $\mathrm{CBD}$ has been shown to prevent and/or reverse increased catalepsy behavior in rodents. When administered before the cataleptic agents haloperidol (antipsychotic drug), L-nitro-N-arginine (non-selective inhibitor of nitric oxide synthase) or WIN 55212,2 (agonist of cannabinoid receptors), CBD hinders the cataleptic behavior in a dose-dependent manner (Gomes et al., 2013). A possible role of the activation of serotonin receptors $5-\mathrm{HT}_{1 \mathrm{~A}}$ in this action has been proposed, because this effect of $\mathrm{CBD}$ is blocked by the pre-treatment with the $5-\mathrm{HT}_{1 \mathrm{~A}}$ antagonist

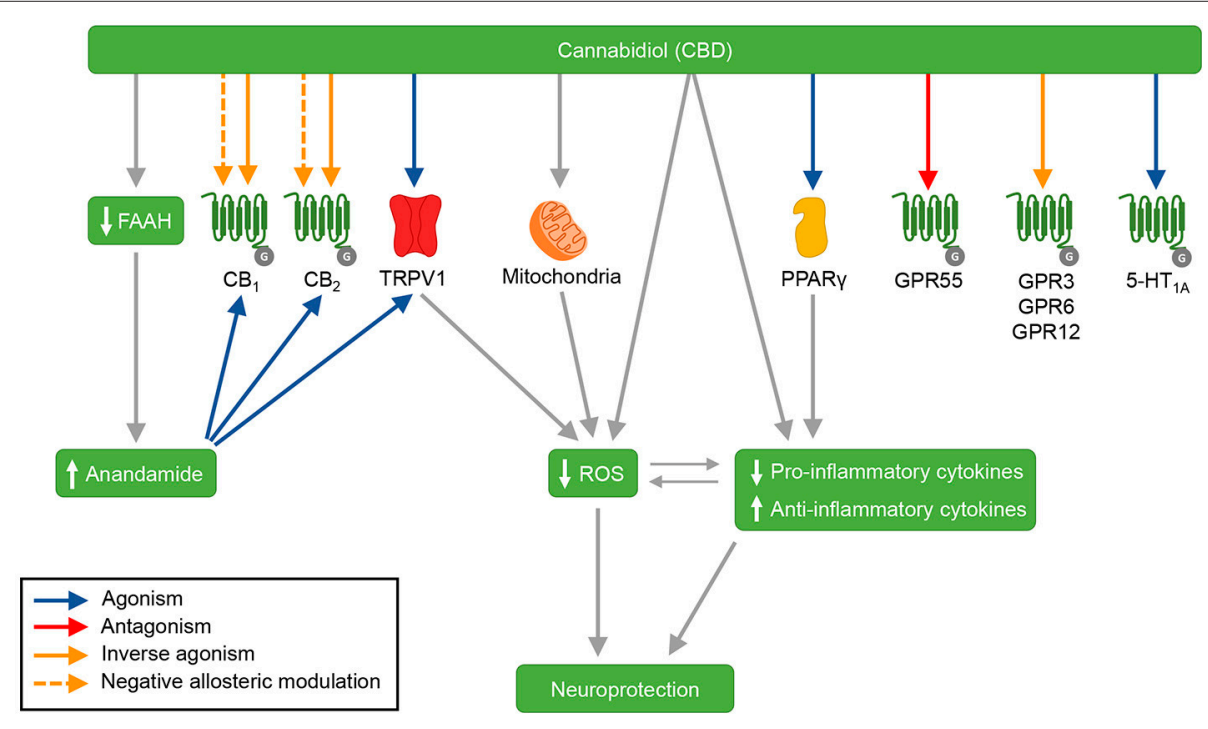

FIGURE 1 | CBD's mechanisms of action. CBD acts as agonist of the receptors TRPV1, PPAR 7 , and 5-HT 1 A, and as antagonist of the receptor GPR55. CBD is an inverse agonist of the receptors GPR3, GPR6, and GPR12. Moreover, CBD antagonizes the action of $\mathrm{CB}_{1}$ and $\mathrm{CB}_{2}$ receptors agonists, and is suggested to act as an inverse agonist and a negative allosteric modulator of these receptors. $\mathrm{CBD}$ also inhibits $\mathrm{FAAH}$, which results in increased anandamide levels. Anandamide activates $\mathrm{CB}_{1}, \mathrm{CB}_{2}$, and TRPV1 receptors. By acting on mitochondria, $\mathrm{CBD}$ increases the activity of mitochondrial complexes. In addition, CBD displays antioxidant and anti-inflammatory effects - that are partially mediated by CBD's actions on TRPV1, mitochondria and PPAR $\gamma$. 5-HT 1 A, serotonin receptor $1 \mathrm{~A}$; $\mathrm{CB}_{1}$, cannabinoid receptor type 1; $\mathrm{CB}_{2}$, cannabinoid receptor type 2; FAAH, fatty acid amide hydrolase; GPR3, G-protein-coupled receptor 3; GPR6, G-protein-coupled receptor 6; GPR12, G-protein-coupled receptor 12; GPR55, G-protein-coupled receptor 55; PPAR $\gamma$, peroxisome proliferator-activated receptor gamma; ROS, reactive oxygen species; TRPV1, transient receptor potential vanilloid type 1. 
WAY100635 (Gomes et al., 2013). In accordance, Sonego et al. (2016) showed that CBD diminishes the haloperidol-induced catalepsy and c-Fos protein expression in the dorsal striatum, also by a mechanism dependent on $5-\mathrm{HT}_{1 \mathrm{~A}}$ activation. Moreover, CBD prevents the increased catalepsy behavior induced by repeated administration of reserpine (Peres et al., 2016).

In addition, pre-clinical studies in animal models of PD have shown neuroprotective effects of CBD. The unilateral injection of the toxin 6-hydroxydopamine (6-OHDA) into the medial forebrain bundle promotes neurodegeneration of nigrostriatal dopaminergic neurons, being used to model PD (Bové et al., 2005). When inside the cell, the neurotoxin 6-OHDA oxidizes in hydrogen peroxide and paraquinone, causing death mainly of catecolaminergic neurons (Breese and Traylor, 1971; Bové et al., 2005). This neurodegeneration leads to depletion of dopamine and decrease in tyrosine hydroxylase activity in caudate-putamen (Bové et al., 2005; Lastres-Becker et al., 2005). Treatment with CBD during the 2 weeks following 6-OHDA administration prevents these effects (Lastres-Becker et al., 2005). In another study, it was observed that CBD's protective effects after 6-OHDA injury are accompanied by elevation of mRNA levels of the antioxidant enzyme $\mathrm{Cu}, \mathrm{Zn}$-superoxide dismutase in substantia nigra (Garcia-Arencibia et al., 2007). The protective effects of $\mathrm{CBD}$ in this model do not seem to depend on the activation of $\mathrm{CB}_{1}$ receptors (Garcia-Arencibia et al., 2007). In addition to preventing the loss of dopaminergic neurons-assessed by tyrosine hydroxylase immunostaining -, the administration of CBD after 6-OHDA injury attenuates the activation of microglia in substantia nigra (Garcia et al., 2011).

In an in vitro study, $\mathrm{CBD}$ increased the viability of cells treated with the neurotoxin N-methyl-4-phenylpyrimidine $(\mathrm{MPP}+)$, and prevented the MPP+-induced increase in caspase3 activation and decrease in levels of nerve growth factor (NGF) (Santos et al., 2015). CBD treatment was also able to induce cell differentiation even in the presence of $\mathrm{MPP}+$, an effect that depends on trkA receptors (Santos et al., 2015). MPP+ is a product of oxidation of MPTP that inhibits complex I of the respiratory chain in dopaminergic neurons, causing a rapid neuronal death (Schapira et al., 1990; Meredith et al., 2008).

Data from clinical and pre-clinical studies are summarized in Tables 1, 2, respectively.

\section{HUNTINGTON'S DISEASE (HD)}

$\mathrm{HD}$ is a fatal progressive neurodegenerative disease characterized by motor dysfunctions, cognitive loss and psychiatric manifestations (McColgan and Tabrizi, 2018). HD is caused by the inclusion of trinucleotides (CAG) in the exons of the huntingtin gene, on chromosome 4 (MacDonald et al., 1993; McColgan and Tabrizi, 2018), and its prevalence is $1-10,000$ (McColgan and Tabrizi, 2018). Neurodegeneration in HD affects mainly the striatal region (caudate and putamen) and this neuronal loss is responsible for the motor symptoms (McColgan and Tabrizi, 2018). Cortical degeneration is seen in later stages, and huntingtin inclusions are seen in few cells, but in all patients with HD (Crook and Housman, 2011). The diagnosis of HD is based on motor signs accompanied by genetic evidence, which is positive genetic test for the expansion of the huntingtin gene or family history (Mason and Barker, 2016; McColgan and Tabrizi, 2018).

The pharmacotherapy of $\mathrm{HD}$ is still directed toward the symptomatic relief of the disease, i.e., the motor disorders believed to be due to dopaminergic hyperactivity. This treatment is often conducted with typical and atypical antipsychotics, but in some cases the use of dopaminergic agonists is needed (Mason and Barker, 2016; McColgan and Tabrizi, 2018). Indeed, the role of dopamine in HD is not fully elucidated yet. Regarding the cognitive deficits, none of the investigated drugs was able to promote improvements (Mason and Barker, 2016; McColgan and Tabrizi, 2018).

Recently, there has been a growing number of studies aiming to verify the therapeutic potential of cannabinoid compounds in the treatment of HD, mainly because some cannabinoids present hypokinetic characteristics (Lastres-Becker et al., 2002). In a controlled clinical trial, patients with $\mathrm{HD}$ were treated with CBD for 6 weeks. There was no significant reduction in the chorea indicators, but no toxicity was observed (Consroe et al., 1991).

The protective effects of CBD and other cannabinoids were also evaluated in a cell culture model of $\mathrm{HD}$, with cells expressing mutated huntingtin. In this model, the induction of huntingtin promotes rapid and extensive cell death (Aiken et al., 2004). $\mathrm{CBD}$ and the other three cannabinoid compounds tested$\Delta^{8}$-THC, $\Delta^{9}$-THC, and cannabinol-show $51-84 \%$ protection against the huntingtin-induced cell death (Aiken et al., 2004). These effects seem to be independent of $\mathrm{CB}_{1}$ activation, since absence of $\mathrm{CB}_{1}$ receptors has been reported in $\mathrm{PC12}$, the cell line used (Molderings et al., 2002). The authors suggest that the cannabinoids exert this protective effect by antioxidant mechanisms (Aiken et al., 2004).

Regarding studies with animal models, treatment with 3nitropropionic acid (3-NP), an inhibitor of complex II of the respiratory chain, induces striatal damage-mainly by calpain activation and oxidative injury -, being suggested as relevant to study HD (Brouillet et al., 2005). Sub-chronic administration of 3-NP in rats reduces GABA contents and the levels of mRNA for several markers of striatal GABAergic neurons projections (Sagredo et al., 2007). In addition, 3-NP diminishes the levels of mRNA for the antioxidant enzymes superoxide dismutase-1 (SOD-1) and -2 (SOD-2) (Sagredo et al., 2007). The administration of CBD reverses or attenuates these 3-NPinduced alterations (Sagredo et al., 2007). CBD's neuroprotective effects are not blocked by the administration of antagonists of the $\mathrm{CB}_{1}$, TRPV1 or $\mathrm{A}_{2 \mathrm{~A}}$ receptors (Sagredo et al., 2007).

More recently, clinical and pre-clinical HD studies started to investigate the effects of Sativex ${ }^{\circledR}$ (CBD in combination with $\Delta^{9}$-THC in an approximately 1:1 ratio). In accordance with what previously seen with $\mathrm{CBD}$ alone, Sativex administration attenuates all the 3-NP induced neurochemical, histological and molecular alterations (Sagredo et al., 2011). These effects do not seem to be linked to activation of $\mathrm{CB}_{1}$ or $\mathrm{CB}_{2}$ receptors (Sagredo et al., 2011). Authors also observed a protective effect of Sativex in reducing the increased expression of iNOS gene induced by malonate (Sagredo et al., 2011). Malonate administration leads to 
TABLE 1 | Clinical studies investigating the effects of CBD on movement disorders.

\begin{tabular}{|c|c|c|c|c|c|}
\hline Disease & Main Findings & $\begin{array}{l}\text { Duration of } \\
\text { Treatment }\end{array}$ & $\begin{array}{l}\text { Dose of CBD and route of } \\
\text { administration }\end{array}$ & Patients characteristics & References \\
\hline PD & $\begin{array}{l}\text { Open-label pilot study. Treatment with } \\
\text { CBD for } 4 \text { weeks diminished the psychotic } \\
\text { symptoms. CBD did not worsen the motor } \\
\text { function or induce adverse effects. }\end{array}$ & 4 weeks & $\begin{array}{l}150 \text { mg/day of CBD, increasing } \\
\text { by } 150 \text { mg every week, } \\
\text { depending on patients' clinical } \\
\text { response. Oral route. }\end{array}$ & $\begin{array}{l}6 \text { PD patients ( } 4 \text { men and } 2 \\
\text { women) with psychosis - not } \\
\text { controlled with reduction of } \\
\text { antiparkinsonian } \\
\text { medications - for at least } 3 \\
\text { months before the beginning of } \\
\text { the study. Patients were in stable } \\
\text { doses of anti-PD medication for } \\
\text { at least } 7 \text { days. }\end{array}$ & Zuardi et al., 2009 \\
\hline PD & $\begin{array}{l}\text { Case series. CBD reduced the frequency } \\
\text { of the events related to REM sleep } \\
\text { behavior disorder. }\end{array}$ & 6 weeks & $\begin{array}{l}75 \text { mg/day ( } 3 \text { patients) or } 300 \\
\text { mg/day (1 patient) of CBD. Oral } \\
\text { route. }\end{array}$ & $\begin{array}{l}4 \text { PD male patients with REM } \\
\text { sleep behavior disorder, with at } \\
\text { least two episodes of complex } \\
\text { sleep-related behaviors per } \\
\text { week. }\end{array}$ & Chagas et al., 2014a \\
\hline PD & $\begin{array}{l}\text { Exploratory double-blind trial. Treatment } \\
\text { with CBD did not improve the motor } \\
\text { function or the general symptoms score, } \\
\text { but the higher dose ( } 300 \mathrm{mg} / \mathrm{kg} \text { ) improved } \\
\text { quality of life. }\end{array}$ & 6 weeks & $\begin{array}{l}75 \text { or } 300 \mathrm{mg} / \text { day of } \mathrm{CBD} \text {. Oral } \\
\text { route. }\end{array}$ & $\begin{array}{l}21 \text { PD patients ( } 15 \text { men and } 6 \\
\text { women) in stable doses of } \\
\text { anti-PD medication for at least } \\
30 \text { days before the beginning of } \\
\text { the study. }\end{array}$ & Chagas et al., 2014b \\
\hline HD & $\begin{array}{l}\text { Controlled clinical trial (double-blind } \\
\text { randomized crossover). Treatment with } \\
\text { CBD did not improve the symptoms, but it } \\
\text { was not toxic. }\end{array}$ & 6 weeks & $\begin{array}{l}10 \mathrm{mg} / \mathrm{kg} / \text { day of } \mathrm{CBD} \text {. Oral } \\
\text { route. }\end{array}$ & $\begin{array}{l}15 \text { patients ( } 8 \text { men and } 7 \\
\text { women) with mild or moderate } \\
\text { progression of HD, not taking } \\
\text { antipsychotic drugs for at least } 2 \\
\text { weeks before the beginning of } \\
\text { the study. }\end{array}$ & Consroe et al., 1991 \\
\hline HD & $\begin{array}{l}\text { Double-blind, randomized, cross-over, } \\
\text { placebo-controlled, pilot trial. Sativex did } \\
\text { not induce severe adverse effects or } \\
\text { clinical worsening. However, Sativex did } \\
\text { not improve patients' symptoms or } \\
\text { promoted molecular changes on } \\
\text { biomarkers. }\end{array}$ & 12 weeks & $\begin{array}{l}\text { Increasing doses of Sativex } \\
\text { (CBD:THC in approximately } 1: 1 \\
\text { ratio) up to } 12 \text { sprays/day. } \\
\text { Intranasal route. }\end{array}$ & $\begin{array}{l}25 \mathrm{HD} \text { ( } 14 \text { men and } 11 \text { women) } \\
\text { patients with stable baseline } \\
\text { medication for at least } 6 \text { weeks } \\
\text { before the beginning of the study. }\end{array}$ & $\begin{array}{l}\text { López-Sendón Moreno } \\
\text { et al., } 2016\end{array}$ \\
\hline$H D$ & $\begin{array}{l}\text { Case report of HD patients treated with } \\
\text { cannabinoid. Cannabinoids improved } \\
\text { UHDRS motor score and dystonia } \\
\text { subscore. }\end{array}$ & 6 or 9 months & $\begin{array}{l}\text { Sativex: } 12 \text { or } 7 \text { sprays/day. } \\
\text { Intranasal route. }\end{array}$ & $\begin{array}{l}2 \text { male HD patients with } \\
\text { complains of severe dystonia. } \\
\text { Duration of the disease: } 14 \text { and } \\
16 \text { years. }\end{array}$ & Saft et al., 2018 \\
\hline $\begin{array}{l}\text { Dystonic } \\
\text { movement } \\
\text { disorders }\end{array}$ & $\begin{array}{l}\text { Open label study. Treatment with CBD } \\
\text { resulted on 20-50\% improvement of the } \\
\text { dystonic symptoms. Two patients with } \\
\text { simultaneous PD's signs showed } \\
\text { worsening of their hypokinesia and/or } \\
\text { resting tremor when receiving the higher } \\
\text { doses of CBD (over } 300 \mathrm{mg} / \text { day). }\end{array}$ & 6 weeks & $\begin{array}{l}\text { Increasing doses of CBD from } \\
100 \text { to } 600 \text { mg/day. Oral route. }\end{array}$ & $\begin{array}{l}5 \text { patients ( } 4 \text { men and } 1 \text { woman) } \\
\text { with dystonic movements, } 2 \text { with } \\
\text { simultaneous parkinsonian } \\
\text { symptoms. }\end{array}$ & Consroe et al., 1986 \\
\hline $\begin{array}{l}\text { Dystonic } \\
\text { movement } \\
\text { disorders }\end{array}$ & $\begin{array}{l}\text { Case report. CBD improved the dystonic } \\
\text { symptoms without inducing adverse } \\
\text { effects. }\end{array}$ & $\begin{array}{l}\text { One } \\
\text { administration }\end{array}$ & CBD 200 mg. Oral route. & $\begin{array}{l}2 \text { patients: one woman with } \\
\text { idiopathic spasmodic torticollis } \\
\text { and one man with generalized } \\
\text { torsion dystonia. }\end{array}$ & Sandyk et al., 1986 \\
\hline
\end{tabular}

CBD, cannabidiol; HD, Huntington's disease; PD, Parkinson's disease; REM, rapid-eye movement; THC, $\Delta^{9}$-tetrahydrocannabinol.

striatal damage by apoptosis and inflammatory events related to glial activation, being used as an acute model for HD (Sagredo et al., 2011; Valdeolivas et al., 2012).

In a subsequent study, it was observed that the administration of a Sativex-like combination attenuates all the malonateinduced alterations, namely: increased edema, decreased number of surviving cells, enhanced number of degenerating cells, strong glial activation, and increased expression of inflammatory markers (iNOS and IGF-1) (Valdeolivas et al., 2012). Although the beneficial effects of Sativex on cell survival are blocked by both $\mathrm{CB}_{1}$ or $\mathrm{CB}_{2}$ antagonists, $\mathrm{CB}_{2}$ receptors seem to have a greater role in the protective effect observed (Valdeolivas et al., 2012).

The beneficial effects of Sativex have also been described in the R6/2 mice, a transgenic model of HD. Treatment with a Sativex-like combination, although not reversing animal's deterioration in rotarod performance, attenuates the elevated clasping behavior, that reflects dystonia (Valdeolivas et al., 2017). 
TABLE 2 | Pre-clinical studies investigating the effects of CBD on movement disorders.

Model
Hamster model of idiopathic paroxysmal
dystonia
PC12 cells expressing mutated huntingtin

Rats lesioned by the toxin 6-OHDA

Rats lesioned by the toxin 6-OHDA

Rats treated with 3-nitropropionic acid (3-NP)

Rats lesioned by the toxin 6-OHDA

Rats treated with 3-nitropropionic acid (3-NP) or malonate

Rats treated with malonate

Mice injected with cataleptic agents

PC12 cells treated with the toxin MPP+

Mice treated with L-DOPA

Rats injected with the cataleptic and dyskinesia-inducing agent reserpine

Mice injected with the cataleptic agent haloperidol

R6/2 mice (transgenic mouse models of HD)

\section{Main findings}

The higher dose of CBD shows a trend to delay the progression of dystonia.

$\mathrm{CBD}$ and the other three cannabinoid compounds tested $-\Delta^{8}-\mathrm{THC}, \Delta^{9}-\mathrm{THC}$, and cannabinol-show 51-84\% protection against the huntingtin-induced cell death. These protective effects seem to be independent of $\mathrm{CB}_{1}$ receptors.

Treatment with CBD for 2 weeks subsequent to lesion by the toxin 6-OHDA prevents the 6-OHDA-induced depletion of dopamine and decrease in tyrosine hydroxylase activity in caudate-putamen.

Treatment with CBD for 2 weeks subsequent to lesion by 6-OHDA prevents the 6-OHDA-induced depletion of dopamine and decrease in tyrosine hydroxylase activity in caudate-putamen. CBD promoted upregulation of mRNA levels for the antioxidant enzyme $\mathrm{Cu}, \mathrm{Zn}$-superoxide dismutase. These protective effects do not seem to depend on activation of $\mathrm{CB}_{1}$ receptors.

Sub-chronic administration of 3-NP reduces GABA contents, levels of mRNA for several markers of striatal GABAergic neurons projections, and the levels of mRNA for the antioxidant enzymes superoxide dismutase-1 (SOD-1) and-2 (SOD-2). CBD reverses or attenuates the 3-NP-induced alterations. CBD's neuroprotective effects are not blocked by antagonists of the $\mathrm{CB}_{1}$, TRPV $\mathrm{V}_{1}$ or $\mathrm{A}_{2 \mathrm{~A}}$ receptors.

Treatment with $\mathrm{CBD}$ for 2 weeks subsequent to lesion by 6-OHDA prevents the 6-OHDA-induced decrease in tyrosine hydroxylase immunostaining, as well as enhanced microglial activation in the substantia nigra.

Sub-chronic administration of 3-NP reduces GABA contents, diminishes the number of Nissl-stained neurons, down-regulates the expression of CB1 receptor and IGF-1, up-regulates the expression of calpain, and reduces the expression of superoxide dismutase-1 (SOD-1). Sativex (CBD and $\Delta^{9}-\mathrm{THC}$ in an approximately $1: 1$ ratio) attenuates all the 3-NP-induced alterations. This effect is not blocked by antagonists of $\mathrm{CB}_{1}$ or $\mathrm{CB}_{2}$ receptors. In addition, rats treated with malonate display increased expression of the iNOS gene, reversed by the administration of Sativex.

Malonate increases edema, decreases the number of surviving cells, enhances the number of degenerating cells, induces strong glial activation, and increases the expression of the inflammatory markers iNOS and IGF-1. Sativex-like combination attenuates all malonate-induced alterations. Sativex effect seems to depend on both $\mathrm{CB}_{1}$ and $\mathrm{CB}_{2}$ receptors.

Pre-treatment with CBD dose-dependently attenuates the increase in catalepsy behavior induced by haloperidol, L-nitro-N-arginine or WIN 55,212-2. CBD's anticataleptic effect is prevented by the administration of WAY100635 (antagonist of 5- $\mathrm{HT}_{1 \mathrm{~A}}$ receptors).

$\mathrm{CBD}$ increases cell viability and prevents the MPP+-induced increase in caspase-3 activation and decrease in levels of NGF. CBD treatment also induces cell differentiation even in the presence of MPP+. CBD's effects on neuritogenesis seem to depend on trkA receptors.

$\mathrm{CBD}$, when administered with capsazepine, an antagonist of $\mathrm{TRPV}_{1}$ receptors, decreases L-DOPA-induced dyskinesia. These effects are blocked by antagonists of $\mathrm{CB}_{1}$ and PPAR $\gamma$ receptors. Treatment with capsazepine and CBD also decreases the expression of inflammatory markers (COX-2 and NFkB).

Repeated administration of reserpine induces catalepsy, hypolocomotion, oral dyskinesia and impairment in the discriminative avoidance memory task. Concomitant treatment with CBD prevents the increase in catalepsy behavior, the oral dyskinesia and the memory deficit.

CBD prevents haloperidol-induced catalepsy and increase in c-Fos protein expression in the dorsolateral striatum. CBD also reverses the increase in catalepsy behavior induced by haloperidol. These CBD effects are prevented by the administration of WAY100635 (antagonist of $5-\mathrm{HT}_{1 \mathrm{~A}}$ receptors). CBD's anticataleptic effect is also observed when CBD is injected into the dorsal striatum.

Treatment with Sativex-like combination (from 4th to 12th weeks after birth) attenuated the $\mathrm{R} 6 / 2$ mice increased clasping behavior (that reflects dystonia) and reduced metabolic activity in basal ganglia. Sativex also reversed some of animals' alterations in markers of brain integrity, but not the deterioration in rotarod performance.
References

Richter and Loscher, 2002

Aiken et al., 2004

Lastres-Becker et al., 2005

Garcia-Arencibia et al., 2007

Sagredo et al., 2007

Garcia et al., 2011

Sagredo et al., 2011

Valdeolivas et al., 2012

Gomes et al., 2013

Santos et al., 2015

Dos-Santos-Pereira et al., 2016

Peres et al., 2016

Sonego et al., 2016

Valdeolivas et al., 2017 
Moreover, treatment mitigates $\mathrm{R} 6 / 2$ mice reduced metabolic activity in basal ganglia and some of the alterations in markers of brain integrity (Valdeolivas et al., 2017).

In spite of the pre-clinical encouraging results with Sativex, a pilot trial with $25 \mathrm{HD}$ patients treated with Sativex for 12 weeks failed to detect improvement in symptoms or molecular changes on biomarkers (López-Sendón Moreno et al., 2016). Nonetheless, Sativex did not induce severe adverse effects or clinical worsening (López-Sendón Moreno et al., 2016). The authors suggest that future studies, with higher doses and/or longer treatment periods, are in need. More recently, one study described the results of administering cannabinoid drugs to 7 patients ( 2 of them were treated with Sativex; the others received dronabinol or nabilone, agonists of the cannabinoid receptors): patients displayed improvement on UHDRS motor score and dystonia subscore (Saft et al., 2018).

Tables 1, 2 summarize data from clinical and pre-clinical studies, respectively.

\section{OTHER MOVEMENT DISORDERS}

Dystonias are the result of abnormal muscles tone, causing involuntary muscle contraction, and resulting in repetitive movements or abnormal posture (Breakefield et al., 2008). Dystonias can be primary, for instance paroxysmal dyskinesia, or secondary to other conditions or drug use, such as tardive dyskinesia after prolonged treatment with antipsychotic drugs (Breakefield et al., 2008).

Consroe et al. (1986) were the first to evaluate the effects of CBD alone in movement disorders. In this open label study, the five patients with dystonic movement disorders displayed 20-50\% improvement of dystonic symptoms when treated with CBD for 6 weeks. Of note, two patients with simultaneous PD's signs showed worsening of their hypokinesia and/or resting tremor when receiving the higher doses of CBD. However, it should be noted that in two more recent studies with PD patients no worsening of motor function was seen (Zuardi et al., 2009; Chagas et al., 2014b). In accordance, Sandyk et al. (1986) reported improvement of dystonic symptoms in two patients-one with idiopathic spasmodic torticollis and one with generalized torsion dystonia-after acute treatment with CBD.

The effects of CBD on dystonic movements were also evaluated in pre-clinical studies. In a hamster model of idiopathic paroxysmal dystonia, the higher dose of CBD showed a trend to delay the progression of dystonia (Richter and Loscher, 2002). In addition, CBD prevents the increase in vacuous chewing movements, i.e., dyskinesia, promoted by repeated administration of reserpine (Peres et al., 2016). CBD's beneficial effects are also seen in L-DOPA-induced dyskinesia in rodents, but only when CBD is administered with capsazepine, an antagonist of TRPV1 receptors (DosSantos-Pereira et al., 2016). These effects seem to depend on $\mathrm{CB}_{1}$ and PPAR $\gamma$ receptors (Dos-Santos-Pereira et al., 2016). In addition, treatment with capsazepine and CBD decreases the expression of inflammatory markers, reinforcing the suggestion that the anti-inflammatory actions of CBD may be beneficial to the treatment of dyskinesia (Dos-Santos-Pereira et al., 2016).

Moreover, Sativex has been used in the treatment of spasticity in multiple sclerosis. Spasticity is a symptom that affects up to $80 \%$ of patients with multiple sclerosis and is associated with poorer quality of life (Flachenecker et al., 2014). A significant portion of patients does not respond to the conventional anti-spasmodic therapies, and some strategies are invasive, posing risks of complications (Flachenecker et al., 2014; Crabtree-Hartman, 2018). Recent data point to Sativex as a valid and well-tolerated therapeutic option. Sativex is able to treat the spasms, improving the quality of life, and displays a low incidence of adverse effects (Giacoppo et al., 2017a).

Data from clinical and pre-clinical studies are summarized in Tables 1, 2, respectively.

\section{SAFETY AND SIDE EFFECTS}

One important concern is whether $\mathrm{CBD}$ is a safe therapeutic strategy. Several preclinical and clinical reports show that CBD does not alter metabolic and physiological parameters, such as glycemia, prolactin levels, blood pressure, and heart rate. In addition, CBD does not modify hematocrit, leukocyte and erythrocyte counts, and blood levels of bilirubin and creatinine in humans. $\mathrm{CBD}$ also does not affect urine osmolarity, $\mathrm{pH}$, albumin levels, and leukocyte and erythrocyte counts. Moreover, in vitro studies demonstrate that $\mathrm{CBD}$ does not alter embryonic development nor the vitality of non-tumor cell lines. The most reported side effects of $\mathrm{CBD}$ are tiredness, diarrhea, and changes on appetite. CBD does not seem to induce tolerance. For a broad review of CBD's side effects, see Bergamaschi et al. (2011) and Iffland and Grotenhermen (2017).

In the context of movement disorders with concomitant cognitive symptoms, as the ones discussed here, it is crucial to evaluate the potential motor and cognitive side effects of CBD. CBD does not induce catalepsy behavior in rodents-being even able to attenuate the effects of several cataleptic agents, as discussed above (El-Alfy et al., 2010; Gomes et al., 2013; Peres et al., 2016; Sonego et al., 2016). In accordance, CBD does not induce extrapyramidal effects in humans (Leweke et al., 2012).

With respect to cognitive effects, studies report that $\mathrm{CBD}$ does not impair cognition, being even able to improve it in some conditions. Pre-clinical data show that CBD restores the deficit in the novel object recognition task in mice treated with MK-801 (a protocol used to model schizophrenia) (Gomes et al., 2015), in rats submitted to neonatal iron overload (Fagherazzi et al., 2012), in a transgenic mice model for Alzheimer's disease (Cheng et al., 2014), and in a mice model for cerebral malaria (Campos et al., 2015). CBD also reverses impaired social recognition in a murine model for Alzheimer's disease (Cheng et al., 2014) and restores the deficits in the Morris water maze-a task that evaluates spatial learning-in rodent models for Alzheimer's disease (Martín-Moreno et al., 2011), brain ischemia (Schiavon et al., 2014) and cerebral malaria (Campos et al., 2015). In addition, 
studies demonstrate that CBD per se does not modify animals' performance in cognitive tasks (Osborne et al., 2017; Myers et al., 2018) and does not induce withdrawal after prolonged treatment (Myers et al., 2018). In accordance, in one recent clinical trial using $\mathrm{CBD}$ as an adjunctive therapy for schizophrenia, CBD group displayed greater cognitive improvement (assessed by BACS-Brief Assessment of Cognition in Schizophrenia), although it fell short of significance (McGuire et al., 2018). $\mathrm{CBD}$ also improves facial emotion recognition in cannabis users (Hindocha et al., 2015).

It is noteworthy that in some cases, particularly concerning multiple sclerosis and $\mathrm{HD}$ clinical studies, CBD per se does not seem to be beneficial. However, when CBD is administered with $\Delta^{9}$-THC in a 1:1 ratio, therapeutic effects are observed. Therefore, it is also important to evaluate the interactions between CBD and $\Delta^{9}$-THC as well as the adverse effects of this mixture. Multiple reports point to deleterious effects of $\Delta^{9}$ THC on human cognition, mainly on memory and emotional processing (Colizzi and Bhattacharyya, 2017). On the other hand, studies reveal that $\mathrm{CBD}$ can counteract $\Delta^{9}$-THC detrimental cognitive effects in rodents and monkeys (Wright et al., 2013; Jacobs et al., 2016; Murphy et al., 2017). Nonetheless, this protective effect depends on the doses, on the interval between CBD and $\Delta^{9}$-THC administration, as well as on the behavioral paradigm used. In fact, some pre-clinical studies do not observe the protective effect of $\mathrm{CBD}$ against the $\Delta^{9}$ - THC cognitive effects (Wright et al., 2013; Jacobs et al., 2016) or even show that CBD may potentiate them (Hayakawa et al., 2008). Limited clinical evidence indicate that CBD does not worse $\Delta^{9}$-THC cognitive effects and, depending on the dose, may protect against them (Colizzi and Bhattacharyya, 2017; Englund et al., 2017; Osborne et al., 2017). Multiple clinical studies with Sativex have not observed motor or cognitive adverse effects (Aragona et al., 2009; Rekand, 2014; López-Sendón Moreno et al., 2016; Russo et al., 2016). Nevertheless, one recent open-label study compared multiple sclerosis patients who continued the treatment with Sativex to those who quitted and reported worse balance and decrease in cognitive performance in the continuers (Castelli et al., 2018). In line with these findings, in an observational study with a large population of Italian patients with multiple sclerosis, cognitive/psychiatric disturbances were seen in $3.9 \%$ of the cases (Patti et al., 2016).

\section{CONCLUSIONS}

The data reviewed here point to a protective role of CBD in the treatment and/or prevention of some movement disorders. Although the studies are scarce, CBD seems to be effective on treating dystonic movements, both primary and secondary. It is noteworthy that in some cases, particularly concerning multiple sclerosis and HD, the clinical beneficial effects are observed only when CBD is combined with $\Delta^{9}$-THC in a $1: 1$ ratio (Sativex). In fact, these therapeutic effects are probably due to $\Delta^{9}$-THC, since they are also seen with other cannabinoid agonists (Curtis et al., 2009; Nielsen et al., 2018; Saft et al., 2018). Nonetheless, CBD is shown to diminish the $\Delta^{9}$-THC unwanted effects, such as sedation, memory impairments, and psychosis (Russo and Guy, 2006). Data regarding HD are scarce, but the results of using Sativex in multiple sclerosis are encouraging. Reviews of the clinical use of this compound in the last decade point to effectiveness in the treatment of spasticity as well as improvement in quality of life, with low incidence of adverse effects (Giacoppo et al., 2017a).

In respect to $\mathrm{PD}$, although the pre-clinical studies are promising, the few studies with patients failed to detect improvement of the motor symptoms after treatment with CBD. There is a significant difference between the clinical and preclinical PD studies. In animals, the beneficial effects are seen when $\mathrm{CBD}$ is administered prior to or immediately after the manipulation that induces the PD-like symptoms. Of note, when treatment with $\mathrm{CBD}$ commences 1 week after the lesion with 6-OHDA, the protective effects are not seen (Garcia-Arencibia et al., 2007). These data suggest that CBD's might have a preventive role rather than a therapeutic one in PD. In clinical practice, $\mathrm{PD}$ is diagnosed subsequently to the emergence of motor symptoms - that appear up to 10 years after the beginning of neurodegeneration and the onset of non-motor symptoms (Schrag et al., 2015). When the diagnosis occur, approximately $60 \%$ of the dopaminergic neurons has already been lost (Dauer and Przedborski, 2003). The fact that in clinical trials CBD is administered only after this substantial progression of the disease might explain the conflicting results. Unfortunately, the early diagnosis of PD remains a challenge, posing difficulty to the implementation of preventive strategies. The development of diagnosis criteria able to detect PD in early stages would probably expand the CBD's applications in this disease.

The molecular mechanisms associated with CBD's improvement of motor disorders are likely multifaceted. Data show that it might depend on CBD's actions on $5-\mathrm{HT}_{1 \mathrm{~A}}$, $\mathrm{CB}_{1}, \mathrm{CB}_{2}$, and/or PPAR $\gamma$ receptors. Moreover, all movement disorders are in some extent linked to oxidative stress and inflammation, and $\mathrm{CBD}$ has been reported to display an antioxidant and anti-inflammatory profile, in vitro and in animal models for movement abnormalities.

The studies investigating the role of CBD on the treatment of movement disorders are few. Furthermore, differences in the dose and duration of treatment as well as in the stage of the disease (for instance, PD patients are treated only in an advanced stage of the disease) among these studies (shown in detail in Table 1) limit the generalization of the positive effect of $\mathrm{CBD}$ and might explain the conflicting results. Notwithstanding, the beneficial neuroprotective profile of CBD added to the preliminary results described here are encouraging. Undoubtedly, future investigations are needed to endorse these initial data and to elucidate the mechanisms involved in the preventive and/or therapeutic potential of CBD on movement disorders.

\section{AUTHOR CONTRIBUTIONS}

All authors listed have made substantial, direct and intellectual contribution to the work, and approved it for publication. 


\section{FUNDING}

VA, JH, and JC are recipients of Conselho Nacional de Desenvolvimento Científico e Tecnológico (CNPq, Brazil) productivity fellowships. Research was supported in part by grants from (i) Fundação de Amparo à Pesquisa do Estado de São Paulo (FAPESP); (ii) Conselho Nacional de Desenvolvimento Científico e Tecnológico (CNPq); (iii) Coordenação de Aperfeiçoamento de Pessoal de Nível Superior

\section{REFERENCES}

Adams, R., Hunt, M., and Clark, J. (1940). Structure of cannabidiol, a product isolated from the marihuana extract of Minnesota wild hemp. I. J. Am. Chem. Soc. 62, 196-200. doi: 10.1021/ja01858a058

Aiken, C. T., Tobin, A. J., and Schweitzer, E. S. (2004). A cell-based screen for drugs to treat Huntington's disease. Neurobiol. Dis. 16, 546-555. doi: 10.1016/j.nbd.2004.04.001

Ammal Kaidery, N., and Thomas, B. (2018). Current perspective of mitochondrial biology in Parkinson's disease. Neurochem. Int. doi: 10.1016/j.neuint.2018.03.001. [Epub ahead of print].

Aragona, M., Onesti, E., Tomassini, V., Conte, A., Gupta, S., Gilio, F., et al. (2009). Psychopathological and cognitive effects of therapeutic cannabinoids in multiple sclerosis: a double-blind, placebo controlled, crossover study. Clin. Neuropharmacol. 32, 41-47. doi: 10.1097/WNF.0B013E3181633497

Bergamaschi, M. M., Queiroz, R. H., Zuardi, A. W., and Crippa, J. A. (2011). Safety and side effects of cannabidiol, a Cannabis sativa constituent. Curr. Drug Saf. 6, 237-249. doi: 10.2174/157488611798280924

Bisogno, T., Hanus, L., De Petrocellis, L., Tchilibon, S., Ponde, D. E., Brandi, I., et al. (2001). Molecular targets for cannabidiol and its synthetic analogues: effect on vanilloid VR1 receptors and on the cellular uptake and enzymatic hydrolysis of anandamide. Br. J. Pharmacol. 134, 845-852. doi: 10.1038/sj.bjp.0704327

Bové, J., Prou, D., Perier, C., and Przedborski, S. (2005). Toxin-induced models of Parkinson's disease. NeuroRx 2, 484-494. doi: 10.1602/neurorx.2.3.484

Breakefield, X. O., Blood, A. J., Li, Y., Hallett, M., Hanson, P. I., and Standaert, D. G. (2008). The pathophysiological basis of dystonias. Nat. Rev. Neurosci. 9, 222-234. doi: 10.1038/nrn2337

Breese, G. R., and Traylor, T. D. (1971). Depletion of brain noradrenaline and dopamine by 6-hydroxydopamine. Br. J. Pharmacol. 42, 88-99. doi: 10.1111/j.1476-5381.1971.tb07089.x

Brouillet, E., Jacquard, C., Bizat, N., and Blum, D. (2005). 3-Nitropropionic acid: a mitochondrial toxin to uncover physiopathological mechanisms underlying striatal degeneration in Huntington's disease. J. Neurochem. 95, 1521-1540. doi: $10.1111 / j .1471-4159.2005 .03515 . x$

Brown, K. J., Laun, A. S., and Song, Z. H. (2017). Cannabidiol, a novel inverse agonist for GPR12. Biochem. Biophys. Res. Commun. 493, 451-454. doi: 10.1016/j.bbrc.2017.09.001

Campos, A. C., Brant, F., Miranda, A. S., Machado, F. S., and Teixeira, A. L. (2015). Cannabidiol increases survival and promotes rescue of cognitive function in a murine model of cerebral malaria. Neuroscience 289, 166-180. doi: 10.1016/j.neuroscience.2014.12.051

Campos, A. C., Fogaca, M. V., Sonego, A. B., and Guimaraes, F. S. (2016). Cannabidiol, neuroprotection and neuropsychiatric disorders. Pharmacol. Res. 112, 119-127. doi: 10.1016/j.phrs.2016.01.033

Castelli, L., Prosperini, L., and Pozzilli, C. (2018). Balance worsening associated with nabiximols in multiple sclerosis. Mult. Scler. J. doi: 10.1177/1352458518765649. [Epub ahead of print].

Celorrio, M., Rojo-Bustamante, E., Fernandez-Suarez, D., Saez, E., EstellaHermoso de Mendoza, A., Muller, C. E., et al. (2017). GPR55: a therapeutic target for Parkinson's disease? Neuropharmacology 125, 319-332. doi: 10.1016/j.neuropharm.2017.08.017

Chagas, M. H., Eckeli, A. L., Zuardi, A. W., Pena-Pereira, M. A., SobreiraNeto, M. A., Sobreira, E. T., et al. (2014a). Cannabidiol can improve complex sleep-related behaviours associated with rapid eye movement sleep behaviour
(CAPES); (iv) Fundação de Apoio ao Ensino, Pesquisa e Assistência do Hospital das Clínicas da Faculdade de Medicina de Ribeirão Preto da Universidade de São Paulo (FAEPA, Brazil); (v) Center for Interdisciplinary Research on Applied Neurosciences (NAPNA), University of São Paulo, São Paulo, Brazil (NAPNA); and (vi) National Institute for Translational Medicine (INCT-TM; CNPq/FAPESP, Brazil). JC has a grant from University Global Partnership Network (UGPN)_Global priorities in cannabinoid research excellence.

disorder in Parkinson's disease patients: a case series. J. Clin. Pharm. Ther. 39, 564-566. doi: 10.1111/jcpt.12179

Chagas, M. H., Zuardi, A. W., Tumas, V., Pena-Pereira, M. A., Sobreira, E. T., Bergamaschi, M. M., et al. (2014b). Effects of cannabidiol in the treatment of patients with Parkinson's disease: an exploratory double-blind trial. J. Psychopharmacol. 28, 1088-1098. doi: 10.1177/0269881114550355

Chen, J., Hou, C., Chen, X., Wang, D., Yang, P., He, X., et al. (2016). Protective effect of cannabidiol on hydrogen peroxide induced apoptosis, inflammation and oxidative stress in nucleus pulposus cells. Mol. Med. Rep. 14, 2321-2327. doi: $10.3892 / \mathrm{mmr} .2016 .5513$

Cheng, D., Low, J. K., Logge, W., Garner, B., and Karl, T. (2014). Chronic cannabidiol treatment improves social and object recognition in double transgenic APPswe/PS1E9 mice. Psychopharmacology 231, 3009-3017. doi: 10.1007/s00213-014-3478-5

Cherif, H., Argaw, A., Cecyre, B., Bouchard, A., Gagnon, J., Javadi, P., et al. (2015). Role of GPR55 during axon growth and target innervation. eNeuro 2:ENEURO.0011-15.2015. doi: 10.1523/ENEURO.0011-15.2015

Colizzi, M., and Bhattacharyya, S. (2017). Does cannabis composition matter? differential effects of delta-9-tetrahydrocannabinol and cannabidiol on human cognition. Curr. Addict. Rep. 4, 62-74. doi: 10.1007/s40429-017-0142-2

Connolly, B. S., and Lang, A. E. (2014). Pharmacological treatment of Parkinson disease: a review. JAMA 311, 1670-1683. doi: 10.1001/jama.2014.3654

Consroe, P., Laguna, J., Allender, J., Snider, S., Stern, L., Sandyk, R., et al. (1991). Controlled clinical trial of cannabidiol in Huntington's disease. Pharmacol. Biochem. Behav. 40, 701-708. doi: 10.1016/0091-3057(91)90386-G

Consroe, P., Sandyk, R., and Snider, S. R. (1986). Open label evaluation of cannabidiol in dystonic movement disorders. Int. J. Neurosci. 30, 277-282. doi: $10.3109 / 00207458608985678$

Crabtree-Hartman, E. (2018). Advanced symptom management in multiple sclerosis. Neurol. Clin. 36, 197-218. doi: 10.1016/j.ncl.2017.08.015

Crook, Z. R., and Housman, D. (2011). Huntington's disease: can mice lead the way to treatment? Neuron 69, 423-435. doi: 10.1016/j.neuron.2010.12.035

Curtis, A., Mitchell, I., Patel, S., Ives, N., and Rickards, H. (2009). A pilot study using nabilone for symptomatic treatment in Huntington's disease. Mov. Disord. 24, 2254-2259. doi: 10.1002/mds.22809

da Silva, V. K., de Freitas, B. S., Dornelles, V. C., Kist, L. W., Bogo, M. R., Silva, M. C., et al. (2018). Novel insights into mitochondrial molecular targets of ironinduced neurodegeneration: reversal by cannabidiol. Brain Res. Bull. 139, 1-8. doi: 10.1016/j.brainresbull.2018.01.014

Dauer, W., and Przedborski, S. (2003). Parkinson's disease: mechanisms and models. Neuron 39, 889-909. doi: 10.1016/S0896-6273(03)00568-3

Dickey, A. S., and La Spada, A. R. (2017). Therapy development in Huntington disease: from current strategies to emerging opportunities. Am. J. Med. Genet. A 176, 842-861. doi: 10.1002/ajmg.a.38494

Dos-Santos-Pereira, M., da-Silva, C. A., Guimaraes, F. S., and Del-Bel, E. (2016). Co-administration of cannabidiol and capsazepine reduces L-DOPA-induced dyskinesia in mice: possible mechanism of action. Neurobiol. Dis. 94, 179-195. doi: 10.1016/j.nbd.2016.06.013

El-Alfy, A. T., Ivey, K., Robinson, K., Ahmed, S., Radwan, M., Slade, D., et al. (2010). Antidepressant-like effect of delta9-tetrahydrocannabinol and other cannabinoids isolated from Cannabis sativa L. Pharmacol. Biochem. Behav. 95, 434-442. doi: 10.1016/j.pbb.2010.03.004

ElSohly, M., and Gul, W. (2014). "Constituents of Cannabis sativa," in Handbook of Cannabis, ed R. G. Pertwee (New York, NY: Oxford University Press), 1093. 
Englund, A., Freeman, T. P., Murray, R. M., and McGuire, P. (2017). Can we make cannabis safer? Lancet Psychiatry 4, 643-648. doi: 10.1016/S2215-0366(17)30075-5

Espejo-Porras, F., Fernandez-Ruiz, J., Pertwee, R. G., Mechoulam, R., and Garcia, C. (2013). Motor effects of the non-psychotropic phytocannabinoid cannabidiol that are mediated by 5-HT1A receptors. Neuropharmacology 75 , 155-163. doi: 10.1016/j.neuropharm.2013.07.024

Esposito, G., Scuderi, C., Savani, C., Steardo, L. Jr., De Filippis, D., Cottone, P., et al. (2007). Cannabidiol in vivo blunts beta-amyloid induced neuroinflammation by suppressing IL-1beta and iNOS expression. Br. J. Pharmacol. 151, 1272-1279. doi: 10.1038/sj.bjp.0707337

Esposito, G., Scuderi, C., Valenza, M., Togna, G. I., Latina, V., De Filippis, D., et al. (2011). Cannabidiol reduces Abeta-induced neuroinflammation and promotes hippocampal neurogenesis through PPARgamma involvement. PLoS ONE 6:e28668. doi: 10.1371/journal.pone.0028668

Fagherazzi, E. V., Garcia, V. A., Maurmann, N., Bervanger, T., Halmenschlager, L. H., Busato, S. B., et al. (2012). Memory-rescuing effects of cannabidiol in an animal model of cognitive impairment relevant to neurodegenerative disorders. Psychopharmacology 219, 1133-1140. doi: 10.1007/s00213-0112449-3

Farooqui, T., and Farooqui, A. A. (2011). Lipid-mediated oxidative stress and inflammation in the pathogenesis of Parkinson's disease. Parkinsons. Dis. 2011:247467. doi: 10.4061/2011/247467

Flachenecker, P., Henze, T., and Zettl, U. K. (2014). Spasticity in patients with multiple sclerosis-clinical characteristics, treatment and quality of life. Acta Neurol. Scand. 129, 154-162. doi: 10.1111/ane.12202

Garcia, C., Palomo-Garo, C., Garcia-Arencibia, M., Ramos, J., Pertwee, R., and Fernandez-Ruiz, J. (2011). Symptom-relieving and neuroprotective effects of the phytocannabinoid Delta(9)-THCV in animal models of Parkinson's disease. Br. J. Pharmacol. 163, 1495-1506. doi: 10.1111/j.1476-5381.2011. 01278.x

García-Arencibia, M., Gonzalez, S., de Lago, E., Ramos, J. A., Mechoulam, R., and Fernandez-Ruiz, J. (2007). Evaluation of the neuroprotective effect of cannabinoids in a rat model of Parkinson's disease: importance of antioxidant and cannabinoid receptor-independent properties. Brain Res. 1134, 162-170. doi: 10.1016/j.brainres.2006.11.063

Giacoppo, S., Bramanti, P., and Mazzon, E. (2017a). Sativex in the management of multiple sclerosis-related spasticity: an overview of the last decade of clinical evaluation. Mult. Scler. Relat. Disord. 17, 22-31. doi: 10.1016/j.msard.2017.06.015

Giacoppo, S., Pollastro, F., Grassi, G., Bramanti, P., and Mazzon, E. (2017b). Target regulation of PI3K/Akt/mTOR pathway by cannabidiol in treatment of experimental multiple sclerosis. Fitoterapia 116, 77-84. doi: 10.1016/j.fitote.2016.11.010

Gomes, F. V., Del Bel, E. A., and Guimaraes, F. S. (2013). Cannabidiol attenuates catalepsy induced by distinct pharmacological mechanisms via 5-HT1A receptor activation in mice. Prog. Neuropsychopharmacol. Biol. Psychiatry 46, 43-47. doi: 10.1016/j.pnpbp.2013.06.005

Gomes, F. V., Llorente, R., Del Bel, E. A., Viveros, M. P., Lopez-Gallardo, M., and Guimaraes, F. S. (2015). Decreased glial reactivity could be involved in the antipsychotic-like effect of cannabidiol. Schizophr. Res. 164, 155-163. doi: 10.1016/j.schres.2015.01.015

Grlic, L. (1976). A comparative study on some chemical and biological characteristics of various samples of cannabis resin. Bull. Narc. 14, 37-46.

Hampson, A. J., Grimaldi, M., Axelrod, J., and Wink, D. (1998). Cannabidiol and (-)Delta9-tetrahydrocannabinol are neuroprotective antioxidants. Proc. Natl. Acad. Sci. U.S.A. 95, 8268-8273. doi: 10.1073/pnas.95.14.8268

Hassan, S., Eldeeb, K., Millns, P. J., Bennett, A. J., Alexander, S. P., and Kendall, D. A. (2014). Cannabidiol enhances microglial phagocytosis via transient receptor potential (TRP) channel activation. Br. J. Pharmacol. 171, 2426-2439. doi: $10.1111 /$ bph.12615

Hayakawa, K., Mishima, K., Hazekawa, M., Sano, K., Irie, K., Orito, K., et al. (2008). Cannabidiol potentiates pharmacological effects of Delta(9)tetrahydrocannabinol via $\mathrm{CB}(1)$ receptor-dependent mechanism. Brain Res. 1188, 157-164. doi: 10.1016/j.brainres.2007.09.090

Hecker, M., Paap, B. K., Goertsches, R. H., Kandulski, O., Fatum, C., Koczan, D., et al. (2011). Reassessment of blood gene expression markers for the prognosis of relapsing-remitting multiple sclerosis. PLoS ONE 6:e29648 doi: 10.1371/journal.pone. 0029648

Hind, W. H., England, T. J., and O'Sullivan, S. E. (2016). Cannabidiol protects an in vitro model of the blood-brain barrier from oxygen-glucose deprivation via PPARgamma and 5-HT1A receptors. Br. J. Pharmacol. 173, 815-825. doi: 10.1111/bph.13368

Hindocha, C., Freeman, T. P., Schafer, G., Gardener, C., Das, R. K., Morgan, C. J., et al. (2015). Acute effects of delta-9-tetrahydrocannabinol, cannabidiol and their combination on facial emotion recognition: a randomised, double-blind, placebo-controlled study in cannabis users. Eur. Neuropsychopharmacol. 25, 325-334. doi: 10.1016/j.euroneuro.2014.11.014

Hodges, A., Strand, A. D., Aragaki, A. K., Kuhn, A., Sengstag, T., Hughes, G., et al. (2006). Regional and cellular gene expression changes in human Huntington's disease brain. Hum. Mol. Genet. 15, 965-977. doi: 10.1093/hmg/ddl013

Iffland, K., and Grotenhermen, F. (2017). An update on safety and side effects of cannabidiol: a review of clinical data and relevant animal studies. Cannabis Cannabinoid Res. 2, 139-154. doi: 10.1089/can.2016.0034

Iuvone, T., Esposito, G., Esposito, R., Santamaria, R., Di Rosa, M., and Izzo, A. A. (2004). Neuroprotective effect of cannabidiol, a non-psychoactive component from Cannabis sativa, on beta-amyloid-induced toxicity in PC12 cells. J. Neurochem. 89, 134-141. doi: 10.1111/j.1471-4159.2003.02327.x

Jacobs, D. S., Kohut, S. J., Jiang, S., Nikas, S. P., Makriyannis, A., and Bergman, J. (2016). Acute and chronic effects of cannabidiol on Delta(9)-tetrahydrocannabinol (Delta(9)-THC)-induced disruption in stop signal task performance. Exp. Clin. Psychopharmacol. 24, 320-330. doi: $10.1037 /$ pha0000081

Jankovic, J. (2005). Motor fluctuations and dyskinesias in Parkinson's disease: clinical manifestations. Mov Disord 20 (Suppl. 11), S11-S16. doi: $10.1002 / \mathrm{mds} .20458$

Juknat, A., Rimmerman, N., Levy, R., Vogel, Z., and Kozela, E. (2012). Cannabidiol affects the expression of genes involved in zinc homeostasis in BV-2 microglial cells. Neurochem. Int. 61, 923-930. doi: 10.1016/j.neuint.2011.12.002

Kaplan, J. S., Stella, N., Catterall, W. A., and Westenbroek, R. E. (2017). Cannabidiol attenuates seizures and social deficits in a mouse model of Dravet syndrome. Proc. Natl. Acad. Sci. U.S.A. 114, 11229-11234. doi: 10.1073/pnas.1711351114

Klockgether, T. (2004). Parkinson's disease: clinical aspects. Cell Tissue Res. 318, 115-120. doi: 10.1007/s00441-004-0975-6

Kozela, E., Pietr, M., Juknat, A., Rimmerman, N., Levy, R., and Vogel, Z. (2010). Cannabinoids Delta(9)-tetrahydrocannabinol and cannabidiol differentially inhibit the lipopolysaccharide-activated NF-kappaB and interferon-beta/STAT proinflammatory pathways in BV-2 microglial cells. J. Biol. Chem. 285, 1616-1626. doi: 10.1074/jbc.M109.069294

Laprairie, R., Bagher, A., Kelly, M., and Denovan-Wright, E. (2015). Cannabidiol is a negative allosteric modulator of the cannabinoid CB1 receptor. $\mathrm{Br}$. J. Pharmacol. 172, 4790-4805. doi: 10.1111/bph.13250

Lastres-Becker, I., Hansen, H. H., Berrendero, F., De Miguel, R., Perez-Rosado, A., Manzanares, J., et al. (2002). Alleviation of motor hyperactivity and neurochemical deficits by endocannabinoid uptake inhibition in a rat model of Huntington's disease. Synapse 44, 23-35. doi: 10.1002/syn.10054

Lastres-Becker, I., Molina-Holgado, F., Ramos, J. A., Mechoulam, R., and Fernandez-Ruiz, J. (2005). Cannabinoids provide neuroprotection against 6hydroxydopamine toxicity in vivo and in vitro: relevance to Parkinson's disease. Neurobiol. Dis. 19, 96-107. doi: 10.1016/j.nbd.2004.11.009

Laun, A. S., and Song, Z. H. (2017). GPR3 and GPR6, novel molecular targets for cannabidiol. Biochem. Biophys. Res. Commun. 490, 17-21. doi: $10.1016 / j . b b r c .2017 .05 .165$

Lee, J. L. C., Bertoglio, L. J., Guimaraes, F. S., and Stevenson, C. W. (2017). Cannabidiol regulation of emotion and emotional memory processing: relevance for treating anxiety-related and substance abuse disorders. $\mathrm{Br}$. J. Pharmacol. 174, 3242-3256. doi: 10.1111/bph.13724

Lerner, P. P., Miodownik, C., and Lerner, V. (2015). Tardive dyskinesia (syndrome): current concept and modern approaches to its management. Psychiatry Clin. Neurosci. 69, 321-334. doi: 10.1111/pcn.12270

Leweke, F. M., Piomelli, D., Pahlisch, F., Muhl, D., Gerth, C. W., Hoyer, C., et al. (2012). Cannabidiol enhances anandamide signaling and alleviates psychotic symptoms of schizophrenia. Transl. Psychiatry 2:e94. doi: 10.1038/tp.2012.15 
Long, L. E., Malone, D. T., and Taylor, D. A. (2006). Cannabidiol reverses MK-801induced disruption of prepulse inhibition in mice. Neuropsychopharmacology 31, 795-803. doi: 10.1038/sj.npp.1300838

López-Sendón Moreno, J. L., Garcia Caldentey, J., Trigo Cubillo, P., Ruiz Romero, C., Garcia Ribas, G., Alonso Arias, M. A., et al. (2016). A double-blind, randomized, cross-over, placebo-controlled, pilot trial with Sativex in Huntington's disease. J. Neurol. 263, 1390-1400. doi: $10.1007 / \mathrm{s} 00415-016-8145-9$

MacDonald, M. E., Barnes, G., Srinidhi, J., Duyao, M. P., Ambrose, C. M., Myers, R. H., et al. (1993). Gametic but not somatic instability of CAG repeat length in Huntington's disease. J. Med. Genet. 30, 982-986. doi: 10.1136/jmg.30. 12.982

Martínez-Pinilla, E., Varani, K., Reyes-Resina, I., Angelats, E., Vincenzi, F., Ferreiro-Vera, C., et al. (2017). Binding and signaling studies disclose a potential allosteric site for cannabidiol in cannabinoid CB2 receptors. Front. Pharmacol. 8:744. doi: 10.3389/fphar.2017.00744

Martín-Moreno, A. M., Reigada, D., Ramirez, B. G., Mechoulam, R., Innamorato, N., Cuadrado, A., et al. (2011). Cannabidiol and other cannabinoids reduce microglial activation in vitro and in vivo: relevance to Alzheimer's disease. Mol. Pharmacol. 79, 964-973. doi: 10.1124/mol.111.071290

Mason, S. L., and Barker, R. A. (2016). Advancing pharmacotherapy for treating Huntington's disease: a review of the existing literature. Expert Opin. Pharmacother. 17, 41-52. doi: 10.1517/14656566.2016.1109630

McColgan, P., and Tabrizi, S. J. (2018). Huntington's disease: a clinical review. Eur. J. Neurol. 25, 24-34. doi: 10.1111/ene.13413

McGuire, P., Robson, P., Cubala, W. J., Vasile, D., Morrison, P. D., Barron, R., et al. (2018). Cannabidiol (CBD) as an adjunctive therapy in schizophrenia: a multicenter randomized controlled trial. Am. J. Psychiatry 175, 225-231. doi: 10.1176/appi.ajp.2017.17030325

Mecha, M., Torrao, A. S., Mestre, L., Carrillo-Salinas, F. J., Mechoulam, R., and Guaza, C. (2012). Cannabidiol protects oligodendrocyte progenitor cells from inflammation-induced apoptosis by attenuating endoplasmic reticulum stress. Cell Death Dis. 3:e331. doi: 10.1038/cddis.2012.71

Mechoulam, R., and Shvo, Y. (1963). Hashish-I: the structure of cannabidiol. Tetrahedron 19, 2073-2078. doi: 10.1016/0040-4020(63)85022-X

Meredith, G. E., Totterdell, S., Potashkin, J. A., and Surmeier, D. J. (2008). Modeling PD pathogenesis in mice: advantages of a chronic MPTP protocol. Parkinsonism Relat. Disord. 14(Suppl. 2), S112-115. doi: 10.1016/j.parkreldis.2008.04.012

Molderings, G. J., Bonisch, H., Hammermann, R., Gothert, M., and Bruss, M. (2002). Noradrenaline release-inhibiting receptors on PC12 cells devoid of alpha(2(-)) and $\mathrm{CB}(1)$ receptors: similarities to presynaptic imidazoline and edg receptors. Neurochem. Int. 40, 157-167. doi: 10.1016/S0197-0186(01)00076-6

Morales, P., Isawi, I., and Reggio, P. H. (2018). Towards a better understanding of the cannabinoid-related orphan receptors GPR3, GPR6, and GPR12. Drug Metab. Rev. 50, 74-93. doi: 10.1080/03602532.2018.1428616

Morales, P., and Reggio, P. H. (2017). An update on non-CB1, non-CB2 cannabinoid related g-protein-coupled receptors. Cannabis Cannabinoid Res. 2, 265-273. doi: 10.1089/can.2017.0036

Murphy, M., Mills, S., Winstone, J., Leishman, E., Wager-Miller, J., Bradshaw, H., et al. (2017). Chronic adolescent delta(9)-tetrahydrocannabinol treatment of male mice leads to long-term cognitive and behavioral dysfunction, which are prevented by concurrent cannabidiol treatment. Cannabis Cannabinoid Res. 2, 235-246. doi: 10.1089/can.2017.0034

Myers, A. M., Siegele, P. B., Foss, J. D., Tuma, R. F., and Ward, S. J. (2018). Single and combined effects of plant-derived and synthetic cannabinoids on cognition and cannabinoid-associated withdrawal signs in mice. $\mathrm{Br}$. J. Pharmacol. doi: 10.1111/bph.14147. [Epub ahead of print].

Nielsen, S., Germanos, R., Weier, M., Pollard, J., Degenhardt, L., Hall, W., et al. (2018). The Use of Cannabis and Cannabinoids in Treating Symptoms of Multiple Sclerosis: a Systematic Review of Reviews. Curr. Neurol. Neurosci. Rep. 18:8. doi: 10.1007/s11910-018-0814-x

Niranjan, R. (2014). The role of inflammatory and oxidative stress mechanisms in the pathogenesis of Parkinson's disease: focus on astrocytes. Mol. Neurobiol. 49, 28-38. doi: 10.1007/s12035-013-8483-x

Oeckl, P., and Ferger, B. (2016). Increased susceptibility of G-protein coupled receptor 6 deficient mice to MPTP neurotoxicity. Neuroscience 337, 218-223. doi: 10.1016/j.neuroscience.2016.09.021
Oeckl, P., Hengerer, B., and Ferger, B. (2014). G-protein coupled receptor 6 deficiency alters striatal dopamine and cAMP concentrations and reduces dyskinesia in a mouse model of Parkinson's disease. Exp. Neurol. 257, 1-9. doi: 10.1016/j.expneurol.2014.04.010

Osborne, A. L., Solowij, N., and Weston-Green, K. (2017). A systematic review of the effect of cannabidiol on cognitive function: relevance to schizophrenia. Neurosci. Biobehav. Rev. 72, 310-324. doi: 10.1016/j.neubiorev.2016.11.012

O'Sullivan, S. E., Sun, Y., Bennett, A. J., Randall, M. D., and Kendall, D. A. (2009). Time-dependent vascular actions of cannabidiol in the rat aorta. Eur. J. Pharmacol. 612, 61-68. doi: 10.1016/j.ejphar.2009.03.010

Pan, H., Mukhopadhyay, P., Rajesh, M., Patel, V., Mukhopadhyay, B., Gao, B., et al. (2009). Cannabidiol attenuates cisplatin-induced nephrotoxicity by decreasing oxidative/nitrosative stress, inflammation, and cell death. J. Pharmacol. Exp. Ther. 328, 708-714. doi: 10.1124/jpet.108.147181

Patti, F., Messina, S., Solaro, C., Amato, M. P., Bergamaschi, R., Bonavita, S., et al. (2016). Efficacy and safety of cannabinoid oromucosal spray for multiple sclerosis spasticity. J. Neurol. Neurosurg. Psychiatry 87, 944-951. doi: 10.1136/jnnp-2015-312591

Pazos, M. R., Mohammed, N., Lafuente, H., Santos, M., Martinez-Pinilla, E., Moreno, E., et al. (2013). Mechanisms of cannabidiol neuroprotection in hypoxic-ischemic newborn pigs: role of $5 \mathrm{HT}(1 \mathrm{~A})$ and $\mathrm{CB} 2$ receptors. Neuropharmacology 71, 282-291. doi: 10.1016/j.neuropharm.2013.03.027

Pedrazzi, J. F., Issy, A. C., Gomes, F. V., Guimaraes, F. S., and DelBel, E. A. (2015). Cannabidiol effects in the prepulse inhibition disruption induced by amphetamine. Psychopharmacology 232, 3057-3065. doi: 10.1007/s00213-015-3945-7

Peres, F. F., Levin, R., Suiama, M. A., Diana, M. C., Gouvea, D. A., Almeida, V. et al. (2016). Cannabidiol prevents motor and cognitive impairments induced by reserpine in rats. Front. Pharmacol. 7:343. doi: 10.3389/fphar.2016.00343

Perez-Reyes, M., Timmons, M. C., Davis, K. H., and Wall, E. M. (1973). A comparison of the pharmacological activity in man of intravenously administered delta9-tetrahydrocannabinol, cannabinol, and cannabidiol. Experientia 29, 1368-1369. doi: 10.1007/BF01922823

Pertwee, R. G. (2008). The diverse CB1 and CB2 receptor pharmacology of three plant cannabinoids: delta9-tetrahydrocannabinol, cannabidiol and delta9-tetrahydrocannabivarin. Br. J. Pharmacol. 153, 199-215. doi: 10.1038/sj.bjp.0707442

Pertwee, R. G., and Ross, R. A. (2002). Cannabinoid receptors and their ligands. Prostaglandins Leukot. Essent. Fatty Acids 66, 101-121. doi: 10.1054/plef.2001.0341

Rajan, T. S., Giacoppo, S., Iori, R., De Nicola, G. R., Grassi, G., Pollastro, F., et al. (2016). Anti-inflammatory and antioxidant effects of a combination of cannabidiol and moringin in LPS-stimulated macrophages. Fitoterapia 112, 104-115. doi: 10.1016/j.fitote.2016.05.008

Rekand, T. (2014). THC:CBD spray and MS spasticity symptoms: data from latest studies. Eur. Neurol. 71(Suppl. 1), 4-9. doi: 10.1159/000357742

Richter, A., and Loscher, W. (2002). Effects of pharmacological manipulations of cannabinoid receptors on severity of dystonia in a genetic model of paroxysmal dyskinesia. Eur. J. Pharmacol. 454, 145-151. doi: 10.1016/S0014-2999(02)02477-9

Rock, E. M., Bolognini, D., Limebeer, C. L., Cascio, M. G., Anavi-Goffer, S., Fletcher, P. J., et al. (2012). Cannabidiol, a non-psychotropic component of cannabis, attenuates vomiting and nausea-like behaviour via indirect agonism of 5-HT(1A) somatodendritic autoreceptors in the dorsal raphe nucleus. $\mathrm{Br}$. J. Pharmacol. 165, 2620-2634. doi: 10.1111/j.1476-5381.2011.01621.x

Ross, R. A. (2003). Anandamide and vanilloid TRPV1 receptors. Br. J. Pharmacol. 140, 790-801. doi: 10.1038/sj.bjp.0705467

Ross, R. A. (2009). The enigmatic pharmacology of GPR55. Trends Pharmacol. Sci. 30, 156-163. doi: 10.1016/j.tips.2008.12.004

Russo, E. B., Burnett, A., Hall, B., and Parker, K. K. (2005). Agonistic properties of cannabidiol at 5-HT1a receptors. Neurochem. Res. 30, 1037-1043. doi: 10.1007/s11064-005-6978-1

Russo, E., and Guy, G. W. (2006). A tale of two cannabinoids: the therapeutic rationale for combining tetrahydrocannabinol and cannabidiol. Med. Hypotheses 66, 234-246. doi: 10.1016/j.mehy.2005.08.026

Russo, M., De Luca, R., Torrisi, M., Rifici, C., Sessa, E., Bramanti, P., et al. (2016). Should we care about sativex-induced neurobehavioral effects? A 6-month follow-up study. Eur. Rev. Med. Pharmacol. Sci. 20, 3127-3133. 
Ryberg, E., Larsson, N., Sjogren, S., Hjorth, S., Hermansson, N. O., Leonova, J., et al. (2007). The orphan receptor GPR55 is a novel cannabinoid receptor. $\mathrm{Br}$. J. Pharmacol. 152, 1092-1101. doi: 10.1038/sj.bjp.0707460

Saft, C., von Hein, S. M., Lücke, T., Thiels, C., Peball, M., Djamshidian, A., et al. (2018). Cannabinoids for treatment of dystonia in Huntington's disease. J. Huntingtons Dis. doi: 10.3233/JHD-170283. [Epub ahead of print].

Sagredo, O., Pazos, M. R., Satta, V., Ramos, J. A., Pertwee, R. G., and FernandezRuiz, J. (2011). Neuroprotective effects of phytocannabinoid-based medicines in experimental models of Huntington's disease. J. Neurosci. Res. 89, 1509-1518. doi: 10.1002/jnr.22682

Sagredo, O., Ramos, J. A., Decio, A., Mechoulam, R., and Fernandez-Ruiz, J. (2007). Cannabidiol reduced the striatal atrophy caused 3-nitropropionic acid in vivo by mechanisms independent of the activation of cannabinoid, vanilloid TRPV1 and adenosine A2A receptors. Eur. J. Neurosci. 26, 843-851. doi: 10.1111/j.1460-9568.2007.05717.x

Sánchez-López, F., Tasset, I., Aguera, E., Feijoo, M., Fernandez-Bolanos, R., Sanchez, F. M., et al. (2012). Oxidative stress and inflammation biomarkers in the blood of patients with Huntington's disease. Neurol. Res. 34, 721-724. doi: 10.1179/1743132812Y.0000000073

Sandyk, R., Snider, S. R., Consroe, P., and Elias, S. M. (1986). Cannabidiol in dystonic movement disorders. Psychiatry Res. 18:291. doi: 10.1016/0165-1781(86)90117-4

Santos, N. A., Martins, N. M., Sisti, F. M., Fernandes, L. S., Ferreira, R. S., Queiroz, R. H., et al. (2015). The neuroprotection of cannabidiol against $\mathrm{MPP}(+)-$ induced toxicity in PC12 cells involves trkA receptors, upregulation of axonal and synaptic proteins, neuritogenesis, and might be relevant to Parkinson's disease. Toxicol. In Vitro 30(1 Pt B), 231-240. doi: 10.1016/j.tiv.2015.11.004

Sartim, A. G., Guimaraes, F. S., and Joca, S. R. (2016). Antidepressant-like effect of cannabidiol injection into the ventral medial prefrontal cortex-Possible involvement of 5-HT1A and CB1 receptors. Behav. Brain Res. 303, 218-227. doi: 10.1016/j.bbr.2016.01.033

Schapira, A. H., Cooper, J. M., Dexter, D., Clark, J. B., Jenner, P., and Marsden, C. D. (1990). Mitochondrial complex I deficiency in Parkinson's disease. J. Neurochem. 54, 823-827. doi: 10.1111/j.1471-4159.1990.tb02325.x

Schiavon, A. P., Soares, L. M., Bonato, J. M., Milani, H., Guimaraes, F. S., and Weffort de Oliveira, R. M. (2014). Protective effects of cannabidiol against hippocampal cell death and cognitive impairment induced by bilateral common carotid artery occlusion in mice. Neurotox. Res. 26, 307-316. doi: 10.1007/s12640-014-9457-0

Schrag, A., Horsfall, L., Walters, K., Noyce, A., and Petersen, I. (2015). Prediagnostic presentations of Parkinson's disease in primary care: a casecontrol study. Lancet Neurol. 14, 57-64. doi: 10.1016/S1474-4422(14)70287-X

Sonego, A. B., Gomes, F. V., Del Bel, E. A., and Guimaraes, F. S. (2016). Cannabidiol attenuates haloperidol-induced catalepsy and c-Fos protein expression in the dorsolateral striatum via 5 -HT1A receptors in mice. Behav. Brain Res. 309, 22-28. doi: 10.1016/j.bbr.2016.04.042

Stern, C. A. J., da Silva, T. R., Raymundi, A. M., de Souza, C. P., HiroakiSato, V. A., Kato, L., et al. (2017). Cannabidiol disrupts the consolidation of specific and generalized fear memories via dorsal hippocampus CB1 and CB2 receptors. Neuropharmacology 125, 220-230. doi: 10.1016/j.neuropharm.2017. 07.024

Tysnes, O. B., and Storstein, A. (2017). Epidemiology of Parkinson's disease. J. Neural Transm. 124, 901-905. doi: 10.1007/s00702-017-1686-y

Valdeolivas, S., Sagredo, O., Delgado, M., Pozo, M. A., and Fernandez-Ruiz, J. (2017). Effects of a sativex-like combination of phytocannabinoids on disease progression in R6/2 mice, an experimental model of Huntington's disease. Int. J. Mol. Sci. 18:E684. doi: 10.3390/ijms18040684

Valdeolivas, S., Satta, V., Pertwee, R. G., Fernandez-Ruiz, J., and Sagredo, O. (2012). Sativex-like combination of phytocannabinoids is neuroprotective in malonatelesioned rats, an inflammatory model of Huntington's disease: role of CB1 and CB2 receptors. ACS Chem. Neurosci. 3, 400-406. doi: 10.1021/cn200114w

Valvassori, S. S., Bavaresco, D. V., Scaini, G., Varela, R. B., Streck, E. L., Chagas, M. H., et al. (2013). Acute and chronic administration of cannabidiol increases mitochondrial complex and creatine kinase activity in the rat brain. Rev. Bras. Psiquiatr. 35, 380-386. doi: 10.1590/1516-4446-2012-0886

Watzl, B., Scuderi, P., and Watson, R. R. (1991). "Influence of marijuana components (THC and CBD) on human mononuclear cell cytokine secretion in vitro," in Drugs of Abuse, Immunity, and Immunodeficiency, eds H. Friedman, T. W. Klein, and S. Specter (Boston, MA: Springer), 63-70.

Weiss, L., Zeira, M., Reich, S., Har-Noy, M., Mechoulam, R., Slavin, S., et al. (2006). Cannabidiol lowers incidence of diabetes in non-obese diabetic mice. Autoimmunity 39, 143-151. doi: 10.1080/08916930500356674

Wright, M. J. Jr., Vandewater, S. A., and Taffe, M. A. (2013). Cannabidiol attenuates deficits of visuospatial associative memory induced by Delta(9) tetrahydrocannabinol. Br. J. Pharmacol. 170, 1365-1373. doi: 10.1111/bph.12199

Zhang, X. Y., Tan, Y. L., Zhou, D. F., Cao, L. Y., Wu, G. Y., Haile, C. N., et al. (2007). Disrupted antioxidant enzyme activity and elevated lipid peroxidation products in schizophrenic patients with tardive dyskinesia. J. Clin. Psychiatry 68, 754-760. doi: 10.4088/JCP.v68n0513

Zuardi, A. W. (2008). Cannabidiol: from an inactive cannabinoid to a drug with wide spectrum of action. Rev. Bras. Psiquiatr. 30, 271-280. doi: 10.1590/S1516-44462008000300015

Zuardi, A. W., Crippa, J. A., Hallak, J. E., Pinto, J. P., Chagas, M. H., Rodrigues, G. G., et al. (2009). Cannabidiol for the treatment of psychosis in Parkinson's disease. J. Psychopharmacol. 23, 979-983. doi: 10.1177/0269881108096519

Conflict of Interest Statement: JH, and JC are co-inventors (Mechoulam R, JC, Guimaraes FS, AZ, JH, Breuer A) of the patent "Fluorinated CBD compounds, compositions and uses thereof. Pub. No.: WO/2014/108899. International Application No.: PCT/IL2014/050023” Def. US no. Reg. 62193296; 29/07/2015; INPI on 19/08/2015 (BR1120150164927). The University of São Paulo has licensed the patent to Phytecs Pharm (USP Resolution No. 15.1.130002.1.1). The University of São Paulo has an agreement with Prati-Donaduzzi (Toledo, Brazil) to "develop a pharmaceutical product containing synthetic cannabidiol and prove its safety and therapeutic efficacy in the treatment of epilepsy, schizophrenia, Parkinson's disease, and anxiety disorders." JH and JC have received travel support from and are medical advisors of BSPG-Pharm.

The other authors declare that the research was conducted in the absence of any commercial or financial relationships that could be construed as a potential conflict of interest.

Copyright (c) 2018 Peres, Lima, Hallak, Crippa, Silva and Abilio. This is an openaccess article distributed under the terms of the Creative Commons Attribution License (CC BY). The use, distribution or reproduction in other forums is permitted, provided the original author(s) and the copyright owner are credited and that the original publication in this journal is cited, in accordance with accepted academic practice. No use, distribution or reproduction is permitted which does not comply with these terms. 